How to Cite: Minakova, A.A., Chikina, M.V., \& Il'yasov, S.G. (2021) Study of uric acid oxidation reaction products in medium of ammonia or primary amines. Bulletin of the University of Karaganda - Chemistry, 104(4), 30-38. https://doi.org/10.31489/2021Ch4/30-38

UDC 547.785.59

\author{
A.A. Minakova*, M.V. Chikina, S.G. Il'yasov \\ Institute for Problems of Chemical and Energetic Technologies, \\ Siberian Branch of the Russian Academy of Sciences (IPCET SB RAS), Biysk, Russia \\ ('Corresponding author's e-mail: nastya.sinitsyna.1994@mail.ru)
}

\title{
Study of uric acid oxidation reaction products in medium of ammonia or primary amines
}

\begin{abstract}
This work is considered in more detail the most important stage of obtaining one of the promising heteroatomic polycyclic compounds 3,7,10-trioxo-2,4,6,8,9,11-hexaaza[3.3.3]propellane (THAP). THAP is a potential compound for creating high-energy substances due to the presence of six nitrogen atoms in the structure and tight packing. Uric acid is the starting compound in the THAP synthesis chain. When it is oxidized by sodium persulfate or potassium ferrocyanide, 1,5-diaminoglycoluril is formed, from which the propellane structure is formed by the tricyclization reaction. This work expanded the range of oxidants for the conversion of uric acid to 1,5-diaminoglycoluril. It was found that 1,5-diaminoglycoluril was formed with a yield of $29 \%$ when using equimolar proportions of uric acid and $\mathrm{KMnO}_{4}$. When using $\mathrm{MnO}_{2}$ in a ten times more excess, the yield of 1,5-diaminoglycoluril was $38 \%$. The article also presents the results of a study of the interaction of uric acid with some amines. The reaction of interaction of uric acid with benzylamine was studied in more detail, the reaction products of which were 4-benzylimino-5-benzylaminoallantoin, 4benzylimino-1-benzylamino-allantoin and 4-benzyliminoallantoin. Based on the synthesis of 4benzyliminoallantoin, a number of promising derivatives of 4 -iminoallantoin were obtained, namely 4ethyliminoallantoin, 4-propyliminoallantoin, 4-i-propyliminoallantoin, 4- $n$-butyliminoallantoin, 4-ibutyliminoallantoin, 4-tert-butyliminoallantoin.
\end{abstract}

Keywords: uric acid, 1,5-diaminoglycoluril, 3,7,10-trioxo-2,4,6,8,9,11-hexaaza[3.3.3]propellane (THAP), oxidative amination, 4-alkyliminoallantoins.

\section{Introduction}

An important task of modern organic chemistry is the discovery of new substances previously unknown to science, which could expand the area of our knowledge and replenish the range of high-energy substances or biologically active products. 3,7,10-Trioxo-2,4,6,8,9,11-hexaaza [3.3.3]propellane (THAP) and its derivatives are the latest products of the heterocycles class, their nitrogen-containing polycyclic structure suggests interesting and useful properties, which determines the undoubted relevance of the topic of this work [1-7]. The synthesis of 3,7,10-trioxo-2,4,6,8,9,11-hexaaza[3.3.3]propellane 7 was proposed by Lee [7] (Figure 1). It can be seen from the reaction scheme that it is necessary to carry out three stages of synthesis to obtain compound 7.

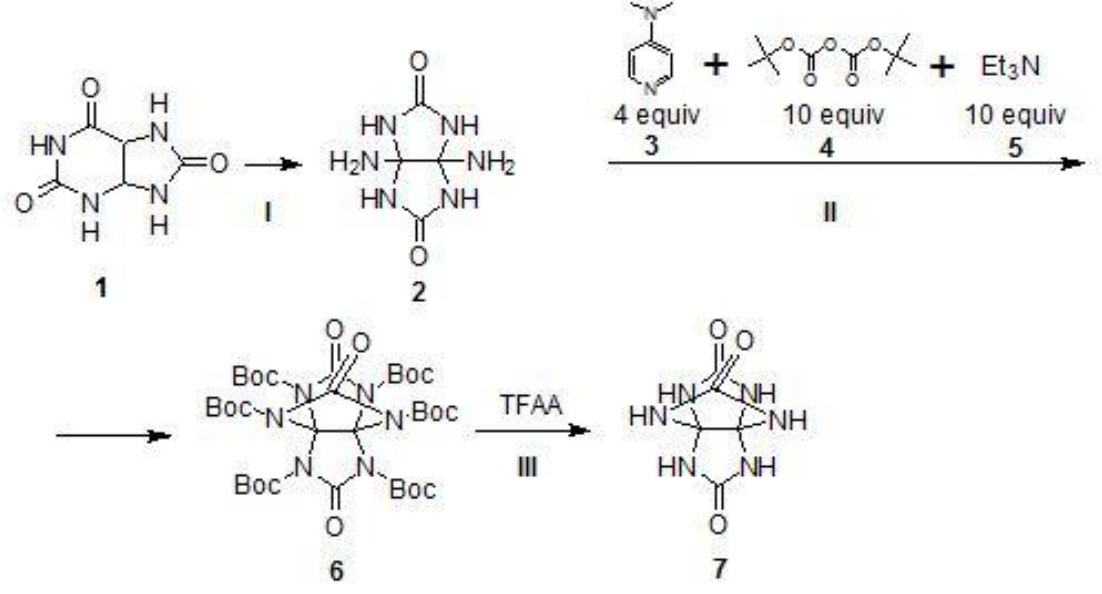

Figure 1. A synthetic protocol for 3,7,10-trioxo-2,4,6,8,9,11-hexaaza[3.3.3]propellane 7 
The first stage involves the oxidation of uric acid 1 by sodium persulfate or potassium ferrocyanide for 1,5-diaminoglycoluril 2 [8,9]. The formation of tricyclic compound $\mathbf{6}$ with six protective groups (Boc) at nitrogen atoms occurs in $69 \%$ yield in the second stage (II). Compound 7 was obtained from compound 6 by treating it with trifluoroacetic acid (stage III) in $91 \%$ yield.

The production of 1,5-diaminoglycoluril (DiAGU) by oxidation of uric acid in ammonia is an important stage in the synthesis of THAP. However, in the literature, the number of oxidants capable of converting uric acid to 1,5-diaminoglycoluril is relatively low. The oxidation products of uric acid can also be 4-iminoallantoin and 5-amino-4-iminoallantoin, the latter compound being an intermediate in the preparation of 1,5-diaminoglycoluril.

The aim of this work is to search for new oxidants of uric acid at the first stage of the process of obtaining 3,7,10-trioxo-2,4,6,8,9,11-hexaaza[3.3.3]propellane, and in the preparation of derivatives of 1,5-diaminoglycoluril.

\section{Experimental}

Synthesis of 1,5-diaminoglycoluril: $0.01 \mathrm{~mol}(1.68 \mathrm{~g})$ of uric acid and $4 \mathrm{~g}$ of sodium chloride are added to $7 \mathrm{ml}$ of water and $15 \mathrm{ml}$ of $25 \%$ aqueous ammonia solution, and the reaction mixture is cooled to $-10{ }^{\circ} \mathrm{C}$. Then $0.04 \mathrm{~mol}(9.52 \mathrm{~g})$ of $\mathrm{Na}_{2} \mathrm{~S}_{2} \mathrm{O}_{8}$ or $0.015 \mathrm{~mol}(2.37 \mathrm{~g})$ of $\mathrm{KMnO}_{4}$ or $0.1 \mathrm{~mol}(8.7 \mathrm{~g})$ of $\mathrm{MnO}_{2}$ are gradually added and the mixture is kept for $2 \mathrm{~h}$ at this temperature, and then $10 \mathrm{ml}$ of $25 \%$ aqueous ammonia solution are added and stirring is raised at room temperature for $1 \mathrm{~h}$. The mother liquor is left at a temperature of $5{ }^{\circ} \mathrm{C}$ for $48 \mathrm{~h}$; the precipitate formed is filtered, washed with water, ethyl alcohol, and diethyl alcohol. The product yield is $69 \%$ (20\% and $38 \%$, respectively). IR, $\mathrm{cm}^{-1}: 3350,3300,1734,1682,1621$. M.p. > $300{ }^{\circ} \mathrm{C}$. NMR ${ }^{1} \mathrm{H}(\delta, \mathrm{ppm}): 7.08(\mathrm{NH}, 4 \mathrm{H}, \mathrm{s}), 2.36\left(\mathrm{NH}_{2}, 4 \mathrm{H}, \mathrm{s}\right) .{ }^{13} \mathrm{C}(\delta, \mathrm{ppm}): 87.72(\mathrm{C}), 158.41$ $(\mathrm{C}=\mathrm{O})$. Calculated (\%): $\mathrm{C} 27.90 ; \mathrm{H} 4.48 ; \mathrm{N} 48.92 \mathrm{C}_{4} \mathrm{H}_{8} \mathrm{~N}_{6} \mathrm{O}_{2}$ Found (\%): $\mathrm{C} 27.91 ; \mathrm{H} 4.68 ; \mathrm{N} 48.82 \%$.

4-benzylimino-5-benzylaminoallantoin (10): $4.76 \mathrm{~g}(0.02 \mathrm{~mol})$ of sodium persulfate was gradually added to a mixture cooled to $-5^{\circ} \mathrm{C}$, consisting of $30 \mathrm{ml}$ of water, $1.68 \mathrm{~g}(0.01 \mathrm{~mol}), 2.14 \mathrm{~g}(0.02 \mathrm{~mol})$ of benzylamine and $4 \mathrm{~g}$ of sodium chloride. The mixture was stirred at a temperature of -8 to $-5^{\circ} \mathrm{C}$ for $2 \mathrm{~h}$, after which the reaction mixture was filtered. Product 10 was collected, washed with water, ethyl alcohol and diethyl ether. The yield was $77 \%$ (2.71 g). M.p. $>300^{\circ} \mathrm{C}$. IR, $\mathrm{cm}^{-1}: 3500,3241,3015,2945,1750,1720$, $1651,1588,1453 . \mathrm{NMR}^{1} \mathrm{H}(400 \mathrm{MHz}, \mathrm{DMSO}-d 6) \delta 3.59\left(\mathrm{t}, 2 \mathrm{H}, \mathrm{NH}_{2}\right), 4.14,4.18,4.27,4.35\left(4 \mathrm{H}, 2 \mathrm{CH}_{2}\right)$, 7.19-7.31 (m, 10CH), $7.84(\mathrm{~s}, 3 \mathrm{H}, 3 \mathrm{NH}) .{ }^{13} \mathrm{C}$ NMR (100 MHz, DMSO-d6) 43.21, 46.43, 80.08 (C $\left.\mathrm{C}_{\text {tert }}\right)$, 127.32-128.54, 137.01, 139.65, $156.12(\mathrm{C}=\mathrm{N}), 168.71(\mathrm{C}=\mathrm{O}), 169.68(\mathrm{C}=\mathrm{O})$.

Synthesis of 4-alkyliminoallantoins. General methodology: $0.01 \mathrm{~mol}$ of uric acid, $7 \mathrm{ml}$ of $25 \%$ aqueous ammonia, $0.02 \mathrm{~mol}$ of primary amine and $4.76 \mathrm{~g}(0.02 \mathrm{~mol})$ of $\mathrm{Na}_{2} \mathrm{~S}_{2} \mathrm{O}_{8}$ were add to $30 \mathrm{ml}$ of distilled water at a temperature of $25^{\circ} \mathrm{C}$, after keeping the reaction mass for $3 \mathrm{~h}$ at this temperature, the product was isolated. When obtaining 13-15, the reaction mass was evaporated 2 times, the precipitate was filtered off. When obtaining 12, 16-18, the resulting precipitate was filtered off immediately after the end of exposure. The resulting precipitates were dried in air to constant weight.

4-benzyliminoallantoin (12). Yield was $78 \%$. ${ }^{1} \mathbf{H}$ NMR (400 MHz, DMSO-d6) 8.63 (1H, t, NH), 7.61 $(1 \mathrm{H}, \mathrm{s}, \mathrm{NH}), 7.26-7.32(5 \mathrm{CH}, \mathrm{m}), 6.81-6.83(1 \mathrm{H}, \mathrm{d}, \mathrm{NH}), 5.79\left(2 \mathrm{H}, \mathrm{s}, \mathrm{NH}_{2}\right), 5.67-5.74(1 \mathrm{H}, \mathrm{d}, \mathrm{NH}), 4.46$ $\left(2 \mathrm{H}, \mathrm{t}, 2 \mathrm{CH}_{2}\right) .{ }^{13} \mathrm{C}$ NMR (100 MHz, DMSO-d6) 169.42, $158.32(\mathrm{C}=\mathrm{N}), 138.81,127.41-128.79,62.80(\mathrm{CH})$, 45.78 .

4-ethyliminoallantoin (13). Yield $67 \%$. ${ }^{1} \mathbf{H}$ NMR (400 MHz, DMSO-d6) $7.24(1 \mathrm{H}, \mathrm{s}, \mathrm{CH}), 5.43(3 \mathrm{H}$, s, $3 \mathrm{NH}), 3.61\left(2 \mathrm{H}, \mathrm{t}, \mathrm{NH}_{2}\right), 2.70-2.74\left(2 \mathrm{H}, \mathrm{m}, \mathrm{CH}_{2}\right), 1.10\left(3 \mathrm{H}, \mathrm{t}, \mathrm{CH}_{3}\right) .{ }^{13} \mathbf{C}$ NMR $(100 \mathrm{MHz}, \mathrm{DMSO}-d 6)$ $177.31(\mathrm{C}=\mathrm{O}), 160.12,158.35(\mathrm{C}=\mathrm{N}), 62.67(\mathrm{CH}), 35.03\left(\mathrm{CH}_{2}\right), 14.38\left(\mathrm{CH}_{3}\right)$.

4-propyliminoallantoin (14). Yield was $69 \% .{ }^{1} \mathbf{H}$ NMR (400 MHz, DMSO-d6) 7.39 (1H, s, CH), 5.41 $(3 \mathrm{H}, \mathrm{s}, 3 \mathrm{NH}), 3.64\left(2 \mathrm{H}, \mathrm{t}, \mathrm{NH}_{2}\right), 2.63-2.67\left(4 \mathrm{H}, \mathrm{m}, 2 \mathrm{CH}_{2}\right), 1.16\left(3 \mathrm{H}, \mathrm{t}, \mathrm{CH}_{3}\right) .{ }^{13} \mathbf{C}$ NMR $(100 \mathrm{MHz}, \mathrm{DMSO}-$ d6) $15.12\left(\mathrm{CH}_{3}\right), 38.37\left(\mathrm{CH}_{2}\right), 64.19(\mathrm{CH}), 158.13(\mathrm{C}=\mathrm{N}), 164.48,176.07(\mathrm{C}=\mathrm{O})$.

4-i-propyliminoallantoin (15). Yield was $74 \%$. ${ }^{1} \mathbf{H}$ NMR $(400 \mathrm{MHz}, \mathrm{DMSO}-d 6) 7.40(1 \mathrm{H}, \mathrm{s}, \mathrm{CH})$, $5.36(3 \mathrm{H}, \mathrm{s}, 3 \mathrm{NH}), 3.51\left(2 \mathrm{H}, \mathrm{t}, \mathrm{NH}_{2}\right), 1.44-1.50\left(3 \mathrm{H}, \mathrm{m}, \mathrm{CH}_{3}\right), 1.22(1 \mathrm{H}, \mathrm{s}, \mathrm{CH}), 0.86-0.90\left(3 \mathrm{H}, \mathrm{m}, \mathrm{CH}_{3}\right) .{ }^{13} \mathbf{C}$ NMR (100 MHz, DMSO- $d 6)$ 177.02 $(\mathrm{C}=\mathrm{O}), 162.61,157.88(\mathrm{C}=\mathrm{N}), 62.48(\mathrm{CH}), 42.06(\mathrm{CH}), 14.09\left(\mathrm{CH}_{3}\right)$.

4-butyliminoallantoin (16). Yield was $73 \%$. ${ }^{1}$ H NMR (400 MHz, DMSO- $\left.d 6\right) 7.53(1 \mathrm{H}, \mathrm{s}, \mathrm{CH}), 5.41$ $(3 \mathrm{H}, \mathrm{s}, 3 \mathrm{NH}), 3.22\left(2 \mathrm{H}, \mathrm{t}, \mathrm{NH}_{2}\right), 2.67-2.74\left(6 \mathrm{H}, \mathrm{m}, 3 \mathrm{CH}_{2}\right), 0.87\left(3 \mathrm{H}, \mathrm{t}, \mathrm{CH}_{3}\right) .{ }^{13} \mathbf{C}$ NMR $(100 \mathrm{MHz}, \mathrm{DMSO}-$ d6) $160.12(\mathrm{C}=\mathrm{O}), 158.29,147.42(\mathrm{C}=\mathrm{N}), 62.67(\mathrm{CH}), 42.17\left(\mathrm{CH}_{2}\right), 30.87\left(\mathrm{CH}_{2}\right), 19.89\left(\mathrm{CH}_{2}\right), 14.11\left(\mathrm{CH}_{3}\right)$.

4-i-butyliminoallantoin (17). Yield was $71 \%$. ${ }^{1} \mathbf{H}$ NMR (400 MHz, DMSO- $\left.d 6\right) 7.56(1 \mathrm{H}, \mathrm{s}, \mathrm{CH}), 5.43$ $(3 \mathrm{H}, \mathrm{s}, 3 \mathrm{NH}), 3.10\left(2 \mathrm{H}, \mathrm{t}, \mathrm{NH}_{2}\right), 2.53\left(2 \mathrm{H}, \mathrm{t}, \mathrm{CH}_{2}\right), 1.86-1.90(1 \mathrm{H}, \mathrm{m}, \mathrm{CH}), 0.88\left(6 \mathrm{H}, \mathrm{t}, 2 \mathrm{CH}_{3}\right) .{ }^{13} \mathbf{C} \mathbf{~ N M R}$ 
$(100 \mathrm{MHz}, \mathrm{DMSO}-d 6) 167.78(\mathrm{C}=\mathrm{O}), 167.51,147.70(\mathrm{C}=\mathrm{N}), 58.42(\mathrm{CH}), 49.82,29.61\left(\mathrm{CH}_{2}\right), 20.89\left(\mathrm{CH}_{3}\right)$, 20.47 .

4-tert-butyliminoallantoin (18). Yield was $79 \% .{ }^{1} \mathbf{H}$ NMR (400 MHz, DMSO-d6) $7.10(1 \mathrm{H}, \mathrm{s}, \mathrm{CH})$, $5.41(3 \mathrm{H}, \mathrm{s}, 3 \mathrm{NH}), 3.21\left(2 \mathrm{H}, \mathrm{t}, \mathrm{NH}_{2}\right), 1.23\left(9 \mathrm{H}, \mathrm{s}, 3 \mathrm{CH}_{3}\right) .{ }^{13} \mathbf{C}$ NMR $(100 \mathrm{MHz}, \mathrm{DMSO}-d 6) 158.32(\mathrm{C}=\mathrm{O})$, $158.31,147.32(\mathrm{C}=\mathrm{N}), 62.81(\mathrm{CH}), 43.29\left(\mathrm{C}_{\text {tert }}\right), 27.61\left(\mathrm{CH}_{3}\right)$.

\section{Results and Discussion}

All reactions were carried out at a temperature of $-5^{\circ} \mathrm{C}$ and a reaction time of $2 \mathrm{~h}$, which is sufficient for complete conversion of uric acid. It was found that not only the yield of $\mathbf{2}$ depended on the molar ratio of the reactants, but the formation of the by-product 4-iminoallantoin 8a was also observed.

Oxidation of uric acid by sodium persulfate

It was identified that the oxidation of $\mathbf{1}$ by $\mathrm{Na}_{2} \mathrm{~S}_{2} \mathrm{O}_{8}$ at a molar ratio of $1: 1$ led to the formation of $\mathbf{8 a}$ only (Fig. 2).

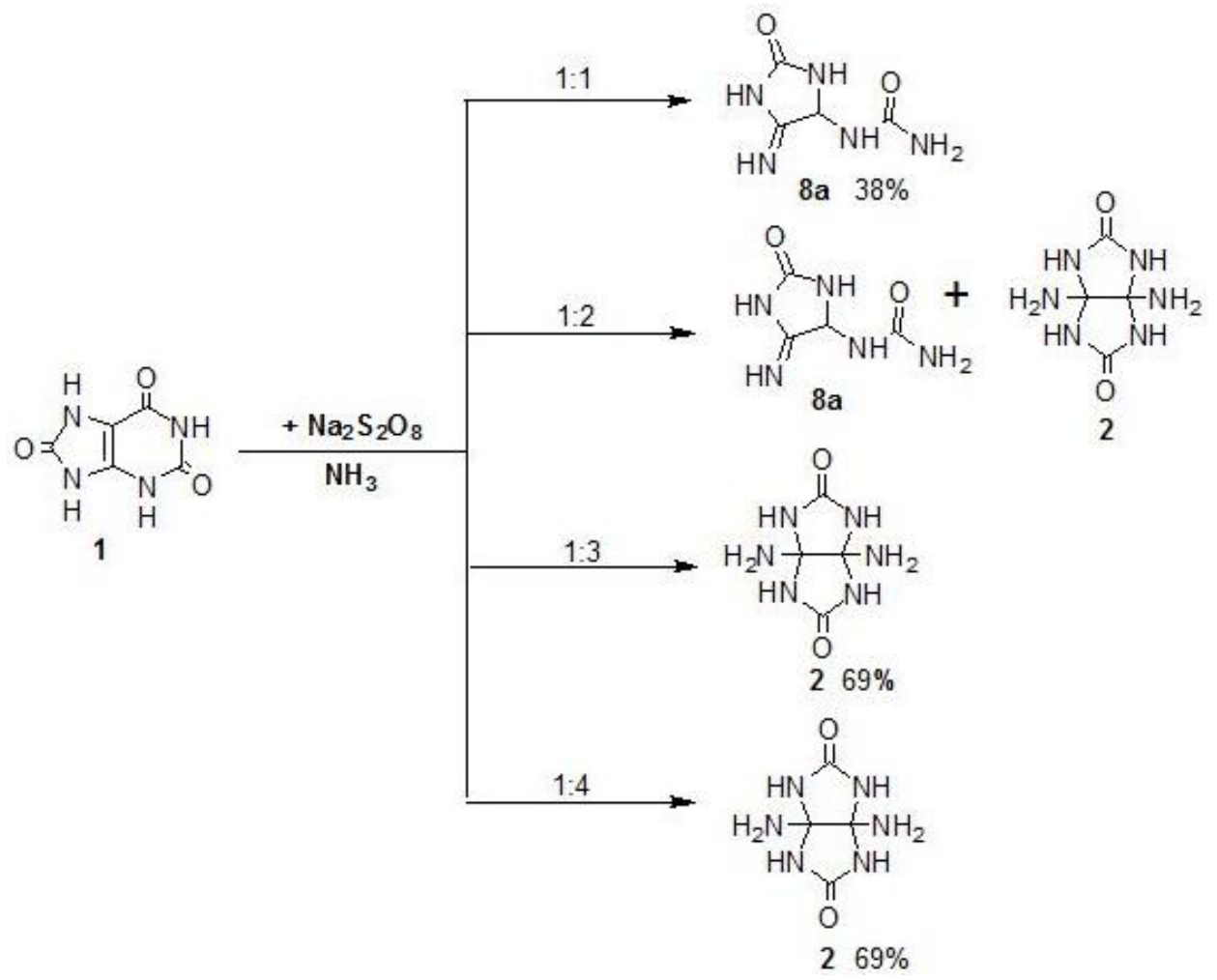

Figure 2. Oxidation of uric acid $\mathbf{1}$ by sodium persulfate

In the [8], the oxidation process of $\mathbf{1}$ by potassium ferrocyanide was studied, where two compounds $\mathbf{8 a}$ and $\mathbf{8 b}$ were found as intermediate reaction products, using a labeled carbon atom (Fig. 3).<smiles>N=C1NC(=O)NC1NC(N)=O</smiles>

$8 a$<smiles>N=C1NC(=O)NC1(N)NC(N)=O</smiles>

$8 b$

Figure 3. 4-iminoallantoin 8a and 4-imino-5-aminoallantoin $\mathbf{8 b}$

Only the structure of intermediate 8a was found in our studies, using heteronuclear NMR spectroscopy. The presence of a proton at position 5 is characterized by two doublets in the proton spectrum in the range of 6.76-6.78 ppm and 5.56-5.58 ppm, as well as a peak at $62.85 \mathrm{ppm}$ characteristic of the $\mathrm{CH}$ bond in the ${ }^{13} \mathrm{C}$ spectrum (Fig. 4). 


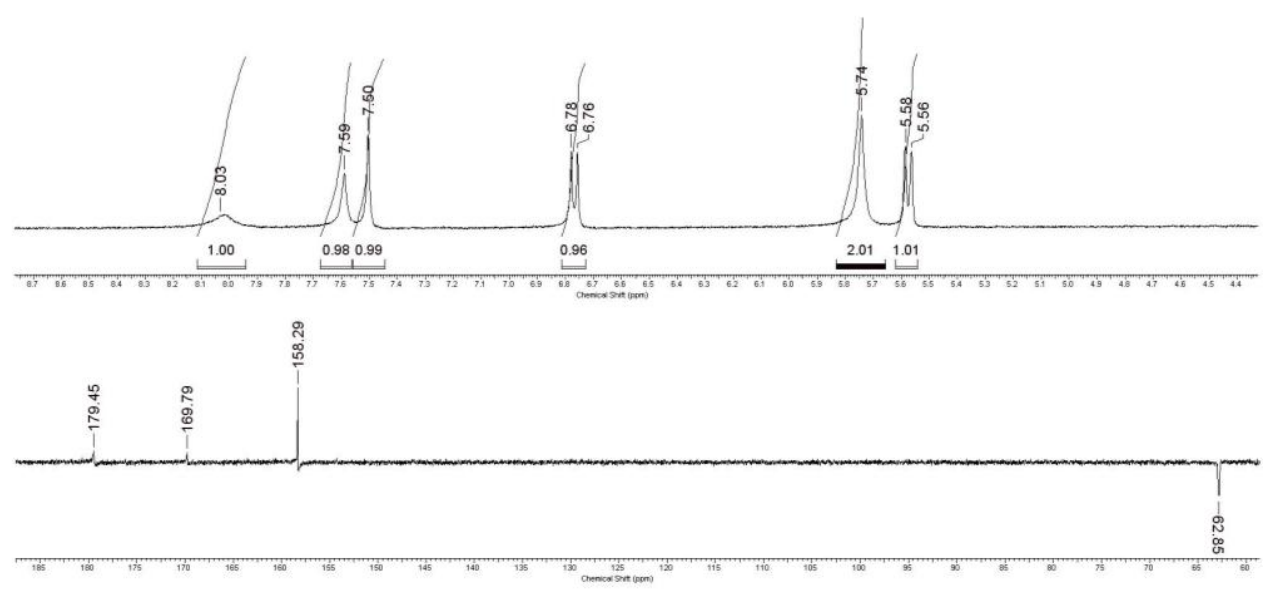

Figure 4. ${ }^{1} \mathrm{H}$ NMR spectrum and ${ }^{13} \mathrm{C}$ NMR spectrum of compound 8a

A two times more increase in the amount of the oxidizing agent led to the formation of an intractable mixture, 2 and 8a. At molar ratios of 1:3 and 1:4, 1,5-diaminoglycoluril is selectively formed, with almost the same yield of $69 \%$ (Fig. 2). The reaction of 1 with ammonia does not proceed without an oxidizing agent.

Oxidation of uric acid by potassium permanganate

The amount of $\mathrm{KMnO}_{4}$ was varied in order to find the optimal conditions for obtaining 2 , and, as a result, the pattern presented in Figure 5 was revealed.

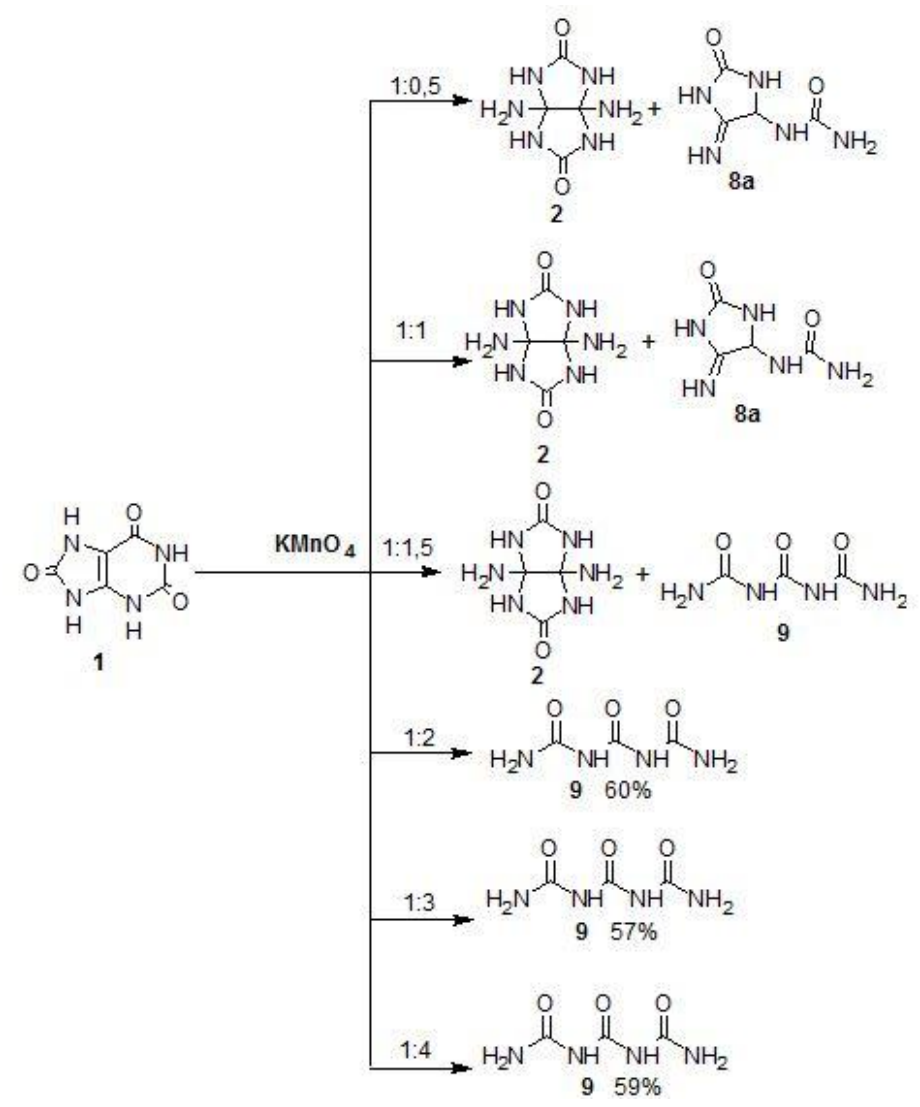

Figure 5. Oxidation of uric acid $\mathbf{1}$ by potassium permanganate

At molar ratios of 1:0.5 and 1:1 of uric acid $\mathbf{1}$ with $\mathrm{KMnO}_{4}$, products $\mathbf{2}$ and $\mathbf{8 a}$ are formed. An increase in the amount of the oxidizing agent leads to the formation of compound $\mathbf{9}$ - triuret, which is described in the literature [10]. In all cases, 1,5-diaminoglycoluril 2 is present in the product mixture. 
Potassium permanganate $\mathrm{KMnO}_{4}$ is converted to $\mathrm{MnO}_{2}$ (II), which must be converted into a watersoluble $\mathrm{MnCl}_{2}$ salt to isolate reaction products $\mathbf{2}$ and $\mathbf{8 a}$.

With an increase in the reaction time to $4 \mathrm{~h}$ at a temperature of $-5^{\circ} \mathrm{C}$ and with a molar ratio of 1: $\mathrm{KMnO}_{4} 1: 1$, the reaction product is only 2 with a yield of $20 \%$ (Fig. 6).

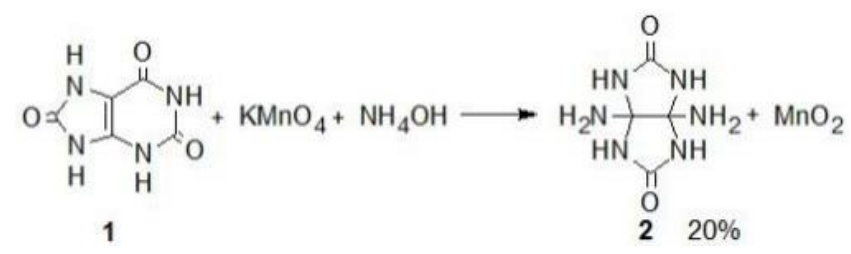

Figure 6. Selective synthesis of 1,5-diaminoglycoluril 2 through the oxidation of uric acid by potassium permanganate

Oxidation of uric acid by manganese (IV) oxide

The using of small amounts of $\mathrm{MnO}_{2}$ does not allow to complete conversion; the only reaction product is 8a (Fig. 7). It is necessary to use a 10 -fold excess of $\mathrm{MnO}_{2}$ for the conversion of uric acid to DiAGU with a yield of $34 \%$. An increase in the reaction time to 4 hours slightly increases the yield of the target product to $38 \%$.

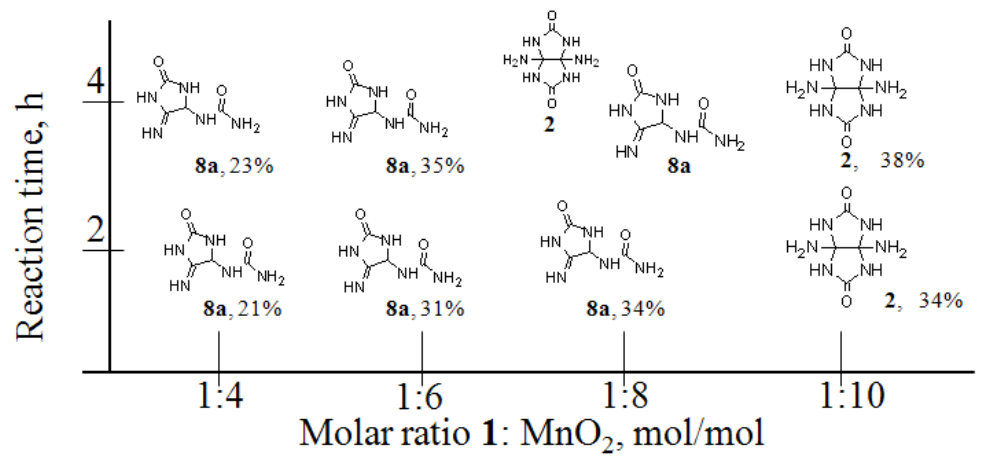

Figure 7. Products of the oxidation reaction of uric acid by $\mathrm{MnO}_{2}$, depending on the molar ratio and duration of the reaction

Thus, it was determined that 1,5-diaminoglycoluril could be obtained by oxidation of uric acid by sodium persulfate, potassium permanganate, and manganese (IV) oxide in $69 \%, 20 \%$ and $38 \%$ yields, respectively.

Some compounds were investigated, namely $\mathrm{BaO}, \mathrm{V}_{2} \mathrm{O}_{5}, \mathrm{CuO}, \mathrm{Cr}_{2} \mathrm{O}_{3}, \mathrm{KClO}_{3}$ in the ratio of uric acid : oxidant 1:4 and 1:10 to expand the range of oxidants for the conversion of uric acid into 1,5-diaminoglycoluril. It was found that the listed oxidants did not undergo conversion of uric acid; therefore, the mixture of the starting compound and the oxidizing agent was quantitatively recovered.

We put forward a hypothesis that replacing ammonia with primary amines will result in the formation of a glycoluril structure with various substituents, which would make it possible to expand the range of derivatives of 3,7,10-trioxo-2,4,6,8,9,11-hexaaza[3.3.3]propellane. Figure 8 illustrates a possible synthesis of substituted hexaazapropellanes.

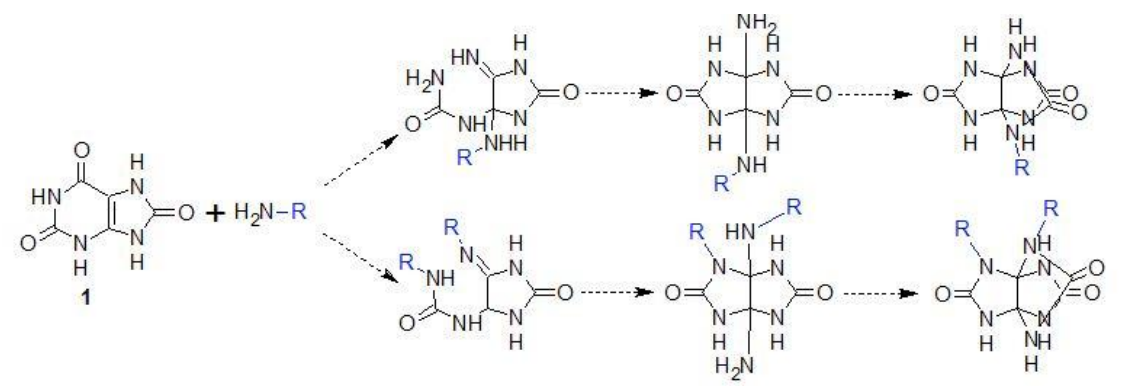

Figure 8. Presumptive scheme for obtaining derivatives of 3,7,10-trioxo-2,4,6,8,9,11-hexaaza[3.3.3]propellane with both the same and different types of substituents 
At the first stage, the effect of the molar ratio of reactants on the oxidation of uric acid by sodium persulfate in the presence of benzylamine was investigated. It was found that the interaction of uric acid 1 with benzylamine in a molar ratio of 1: 4 in an aqueous medium in the presence of the oxidizing agent $\mathrm{Na}_{2} \mathrm{~S}_{2} \mathrm{O}_{8}$ led to the formation of a mixture of products, namely 4-benzylimino-5-benzylaminoallantoin $\mathbf{1 0}$ and 4-benzylimino-1-benzylaminoallantoin 11. With a decrease in the amount of benzylamine to $1: 3$ and 1:2, 4-benzylimino-5-benzylaminoallantoin $\mathbf{1 0}$ was isolated as a reaction product; at a molar ratio of 1:2, the yield of $\mathbf{1 0}$ was higher. Compound $\mathbf{1 1}$ without impurity of $\mathbf{1 0}$ cannot be isolated (Fig. 9).

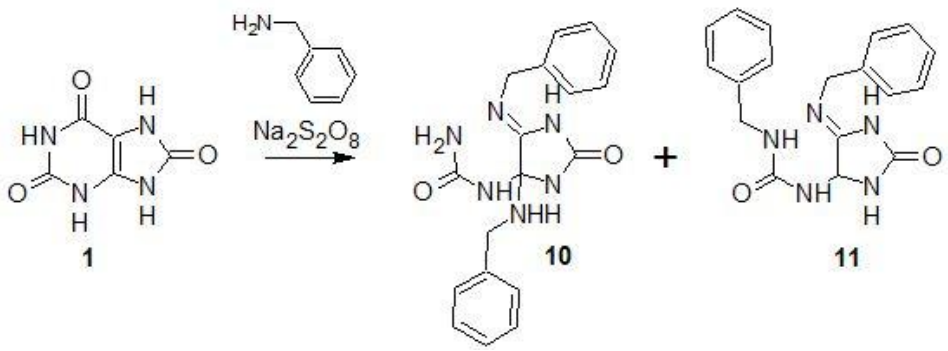

Figure 9. Interaction of uric acid with benzylamine in the presence of sodium persulfate

4-Benzylimino-5-benzylaminoallantoin $\mathbf{1 0}$ does not cyclize to the glycoluril structure, which is probably due to steric effects. It was shown that when $\mathbf{1 0}$ was treated with an aqueous ammonia solution in the presence of $\mathrm{NaCl}$ and at a temperature of $0{ }^{\circ} \mathrm{C}$, the reaction product was 4-benzyliminoallantoin 12 (Fig. 10).
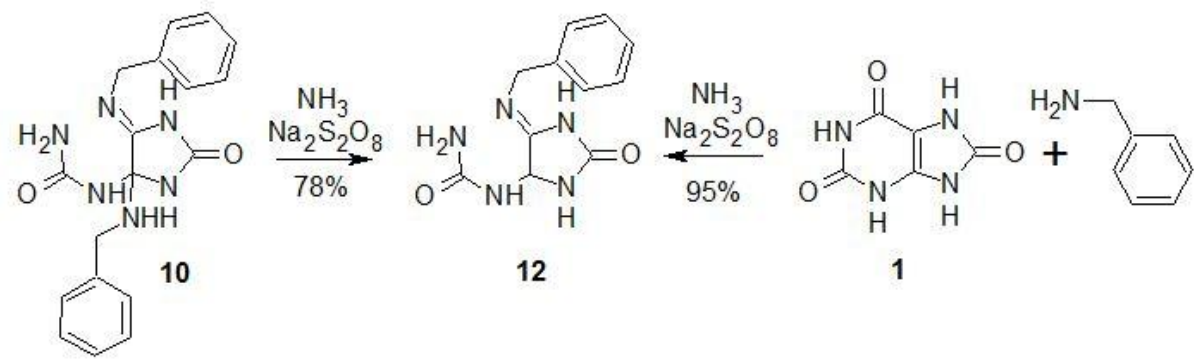

Figure 10. Synthesis of 4-benzyliminoallantoin

As can be seen from Figure 10, during the oxidation of 10, one benzyl group was cleaved off instead of substitution by the amino group. At the same time, the simultaneous interaction of uric acid with benzylamine and ammonia also led to the formation of compound $\mathbf{1 2}$.

Under conditions similar to synthesis of 12, a number of new heterocyclic compounds 13-18 were obtained (Fig. 11).

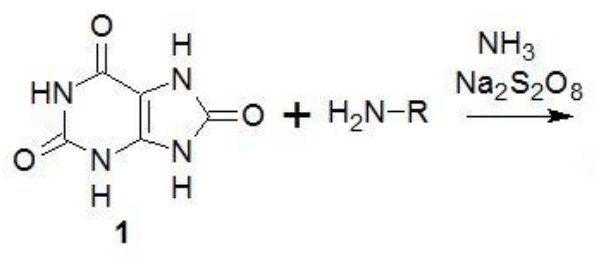<smiles>[R]N=C1NC(=O)NC1NC(N)=O</smiles>

$$
\begin{aligned}
& \text { R: } 13-\mathrm{C}_{2} \mathrm{H}_{5}(67 \%) ; \\
& 14-\mathrm{C}_{3} \mathrm{H}_{7}(69 \%) ; \\
& 15-i-\mathrm{C}_{3} \mathrm{H}_{7}(74 \%) ; \\
& 16-\mathrm{C}_{4} \mathrm{H}_{9}(73 \%) ; \\
& 17-i-\mathrm{C}_{4} \mathrm{H}_{9}(71 \%) ; \\
& 18-t-\mathrm{C}_{4} \mathrm{H}_{9}(61 \%) ;
\end{aligned}
$$

Figure 11. Synthesis of various 4-alkylallantoins 
The structure of all obtained compounds 13-18 was proved using IR and heteronuclear NMR spectroscopy. It was found that the signals of iminoallantoin in all compounds were practically identical; the spectra differ only in the signals of the alkyl fragment.

\section{Conclusions}

Some stages of the synthesis of 3,7,10-trioxo-2,4,6,8,9,11-hexaaza[3.3.3]propellane are considered in more detail. It was illustrated that not only potassium ferrocyanide and sodium persulfate, but also potassium permanganate and manganese (IV) oxide could be used for the synthesis of one of the key starting compounds of 1,5-diaminoglycoluril with a yield of $20 \%$ and $38 \%$, respectively.

A study of the interaction of uric acid with benzylamine in the presence of the oxidizing agent sodium persulfate in an aqueous medium was carried out. It was shown that 4-benzylimino-5-benzylaminoallantoin was formed at a molar ratio of $1: 2$ and 1:3, while an increase in the molar ratio to a 4 -fold excess gave a mixture of 4-benzylimino-5-benzylaminoallantoin and 1-benzylamino-4-benzyliminoallantoin, the latter was formed only in a mixture under the conditions studied by us. 4-Benzyliminoallantoin is formed in two ways:

- One-stage: interaction of uric acid with benzylamine and ammonia;

- Two-stage: at the first stage, the interaction of uric acid with benzylamine occurs with the formation of 4-benzylimino-5-benzylaminoallantoin; in the second stage, the oxidation of 4-benzylimino-5benzylaminoallantoin by sodium persulfate in the presence of ammonia is conducted.

A number of new derivatives of iminoallantoin (4-ethyliminoallantoin, 4-propyliminoallantoin, 4isopropyliminoallantoin, 4- $n$-butyliminoallantoin, 4-isobutyliminoallantoin, 4-tert-butyliminoallantoin, 4propargyliminoallantoin, 4-phenyliminoallantoin) were obtained by the interaction of uric acid with various amines in the presence of the oxidizing agent sodium persulfate in an aqueous medium at a temperature of $25^{\circ} \mathrm{C}$.

\section{Acknowledgments}

The work was carried out on the basic topic № 0308-2021-0003 and using the instrument base of the Biysk Regional Center for Collective Use of the SB RAS (IPCET SB RAS, Biysk).

\section{References}

1 Aizawa N. Instant low-temperature cross-linking of poly(N-vinylcarbazole) for solution-processed multilayer blue phosphorescent organic light-emitting devices / N. Aizawa, Y.-J. Pu, T. Chiba // J. Adv. Mater. — 2014. — Vol. 26. — P. $7543-7546$. https://doi.org/10.1364/SOLED.2014.DW5C.3

2 Oxley J.C. Synthesis and Characterization of Urea Nitrate and Nitrourea / J.C. Oxley, J.L. Smith // J. Propellants, Explos. Pyrotech. - 2013. — Vol. 38. - P. 335-344. https://doi.org/10.1002/prep.201200178

3 Pagoria P.F. 1,1,1-Trimethylhydrazinium iodide: a novel, highly reactive reagent for aromatic amination via vicarious nucleophilic substitution of hydrogen / A.R. Mitchell, E.S. Jessop // J Prop Explos Pyrotech. — 1996. — Vol. 21. — P. 14-18. https://doi.org/10.1021/j0952257z

4 Altman E. Propellanes-I: Tricyclic compounds conjoined in a carbon-carbon single bond / E. Altman, J. Babad, D. Ginsburg // J. Tetrahedron. - 1966. - Vol. 22, S. 8. - P. 279-304.

5 Boileau, J. ChemInform Abstract: Methods for the preparation of nitro and nitroacetylated derivatives of glycoluril / J. Boileau, E. Wimmer, M. Carail, R. Gallo // Chemischer Informationsdienst. - 1986. — Vol. 17, No. 44. https://doi.org/10.1002/ chin.198644179

6 Zhang J. Synthesis, structure characterizations, and theoretical studies of novel tricyclic multiple(urea) molecules / J. Zhang, Y. Liu, F. Bi, J. Zhou, B. Wang // Journal of Molecular Structure. — 2017. — Vol. 1141. — P. 268-275. https://doi.org/10.1016/ j.molstruc.2017.03.092.

7 Lee B. Synthesis of 2,4,6,8,9,11-hexaaza[3.3.3]propellanes as a new molecular skeleton for explosives / B. Lee, M. Shin, Y. Seo, M.H. Kim, H.R. Lee, J.S. Kim, K.-H. Chung, D. Yoo, Y.G. Kim // Tetrahedron. — 2018. — Vol. 74, No. 1 - P. $130-134$. https://doi.org/10.1016/j.tet.2017.11.046

8 Qiu H. Preparation, Crystal Structure, thermal Decomposition, and DFT Calculation of a novel 3D Infinite Structure Coordination Polymer $\left[\mathrm{Na}_{2}\left(\mathrm{H}_{2} \mathrm{O}\right)_{4}(\mathrm{ITDO})_{2}\right] \mathrm{n}$ (ITDO = 2H-imidazo[4,5-e]-as-1,2,4-triazine-2,7-dihydro-3,6-dione) / H. Qiu, J. Rong, Sh. Li // Z. Anorg. Allg. Chem. - 2015. - Vol. 641, No. 2. - P. 424-429. https://doi.org/10.1002/zaac.201400413

9 Popovic T. Synthesis and structure of dehydro-4-iminoallantion and its covalent adducts / T. Popovic, L. Sokolic, N. Modric, A. Palkovic, M. Poje // Tetrahedron. — 1991. — Vol. 47, No. 2. — P. 317-322. https://doi.org/10.1002/chin.199112197

10 Kulasegaram S. Zinc monoglycerolate as a catalyst for the conversion of 1,3- and higher diols to diurethanes / S. Kulasegaram, U. Shaheen, T.W. Turney, W.P. Gatesc, A.F. Patti // RAC Advances. — 2015. — Iss. 59. — P. 47809-47812. https://doi.org/10.1039/C5RA05032D 


\author{
А.А. Минакова, М.В. Чикина, С.Г. Ильясов
}

\title{
Аммиак немесе біріншілік аминдер ортасында несеп қышқылының тотығу реакциясы өнімдерін зерттеу
}

\begin{abstract}
Мақалада перспективалы гетероатомды полициклді қосылыстардың бірі 3,7,10-триоксо-2,4,6,8,9,11гексаза[3.3.3]пропелланды (ТНАР) алудың маңызды кезеңі жан-жақты қарастырылған. Құрылымындағы алты азот атомының болуы себебінен және тығыз орналасуы нәтижесінде ТНАР жоғары энергиялы заттарды жасау үшін қажетті қосылыс болып саналады. Зәр қышқылы ТНАР синтез тізбегіндегі бастапқы қосылыс болып табылады. Оны натрий персульфатымен немесе калий ферроцианидімен тотықтырғанда 1,5-диаминогликолурил және одан трициклдену реакциясы арқылы пропелландық құрылым түзіледі. Осы мақалада несеп қышқылын 1,5-диаминогликолурилге айналдыру үшін тотықтырғыштардың ауқымы кеңейтілген. Несеп қышқылы мен $\mathrm{KMnO}_{4}$ эквимолярлық қатынасын қолданғанда 1,5-диаминогликолурилдың шығымы 20 \% болатыны, ал $\mathrm{MnO}_{2}$ мөлшерін он есе артық қолданғанда 1,5-диаминогликолурил шығымы 38 \% құрайтыны анықталды. Авторлар мақалада сонымен қатар несеп қышқылының кейбір аминдермен әрекеттесуін зерттеу нәтижелерін келтірген. Реакция өнімдері 4-бензилимин-5-бензиламиналлантоин, 4-бензилимин-1бензилиналлантоин және 4-бензилиминаллантоин болып табылатын несеп қышқылының бензиламинмен әрекеттесу реакциясы толығырақ зерттелген. 4-бензилиминаллантоин синтезі негізінде 4-иминаллантоиннің 4-этилиминаллантоин, 4-пропилиминаллантоин, 4-изопропилиминоаллантоин, 4-н-бутилиминаллантоин, 4-изо-бутилиминаллантоин, 4-трет.-бутилиминаллантоин сияқты бірқатар перспективалы туындылары алынды.
\end{abstract}

Кілm сөздер: несеп қышқылы, 1,5-диамингликолурил, 3,7,10-триоксо-2,4,6,8,9,11-гексаза[3.3.3]пропеллан (ТНАР), тотығу аминденуі, 4-алкилиминаллантоиндер.

\section{А.А. Минакова, М.В. Чикина, С.Г. Ильясов}

\section{Исследование продуктов реакции окисления мочевой кислоты в среде аммиака или первичных аминов}

\begin{abstract}
В статье подробно рассмотрен важный этап получения одного из перспективных гетероатомных полициклических соединений - 3,7,10-триоксо-2,4,6,8,9,11-гексааза[3.3.3]пропеллана (ТНАР). Благодаря наличию шести атомов азота в структуре и плотной упаковке ТНАР является потенциальным соединением для создания высокоэнергетических веществ. Мочевая кислота является исходным соединением в цепочке превращения синтеза ТНАР. При ее окислении персульфатом натрия или ферроцианидом калия получается 1,5-диаминогликолурил, из которого реакцией трициклизации образуется структура пропеллана. Авторами расширен ряд окислителей для превращения мочевой кислоты в 1,5-диаминогликолурил. Было обнаружено, что 1,5-диаминогликолурил образуется с выходом $20 \%$ при использовании эквимолярных соотношений мочевой кислоты и $\mathrm{KMnO}_{4}$, а при применении десятикратного избытка $\mathrm{MnO}_{2}$ выход 1,5-диаминогликолурила составил $38 \%$. Кроме того, представлены результаты исследования взаимодействия мочевой кислоты с некоторыми аминами. Подробно изучена реакция взаимодействия мочевой кислоты с бензиламином, продуктами реакции которой являются 4-бензилимино-5-бензиламиноаллантоин, 4-бензилимино-1-бензиламиноаллантоин и 4-бензилиминоаллантоин. На основе синтеза 4-бензилиминоаллантоина был получен ряд перспективных производных 4-иминоаллантоина: 4-этилиминоаллантоин, 4-пропилиминоаллантоин, 4-изопропилиминоаллантоин, 4-н-бутилиминоаллантоин, 4-изо-бутилиминоаллантоин, 4-трет.-бутилиминоаллантоин.
\end{abstract}

Ключевые слова: мочевая кислота, 1,5-диаминогликолурил, 3,7,10-триоксо-2,4,6,8,9,11-гексааза[3.3.3]пропеллан (ТНАР), окислительное аминирование, 4-алкилиминоаллантоины.

\section{References}

1 Aizawa, N., Pu, Y., Chiba, T., Kawata, S., Sasabe, H., \& Kido, J. (2014). Organic Light-Emitting Devices: Instant LowTemperature Cross-Linking of Poly(N-vinylcarbazole) for Solution-Processed Multilayer Blue Phosphorescent Organic LightEmitting Devices (Adv. Mater. 45/2014). Advanced Materials, 26(45), 7675-7675. doi: 10.1002/adma.201470311

2 Oxley, J.C., Smith, J.L., Vadlamannati, S., Brown, A.C., Zhang, G., Swanson, D.S., \& Canino, J. (2013). Synthesis and Characterization of Urea Nitrate and Nitrourea. Propellants, Explosives, Pyrotechnics, 38(3), 335-344. doi: 10.1002/prep.201200178

3 Pagoria, P.F., Mitchell, A.R., \& Schmidt, R.D. (1996). 1,1,1-Trimethylhydrazinium Iodide: A Novel, Highly Reactive Reagent for Aromatic Amination via Vicarious Nucleophilic Substitution of Hydrogen. The Journal of Organic Chemistry, 61(9), 29342935. doi:10.1021/jo952257z 
4 Altman E., Babad, J. \&, Ginsburg, D. (1966). Propellanes-I: Tricyclic Compounds Conjoined in a Carbon-carbon Single Bond. J. Tetrahedron, 22(8), 279-304.

5 Boileau, J., Wimmer, E., Carail, M., \& Gallo, R. (1986). ChemInform Abstract: Methods for the Preparation of Nitro and Nitroacetylated Derivatives of Glycoluril. Chemischer Informationsdienst, 17(44). doi: 10.1002/chin.198644179

6 Zhang, J., Liu, Y., Bi, F., Zhou, J., \& Wang, B. (2017). Synthesis, structure characterizations, and theoretical studies of novel tricyclic multiple(urea) molecules. Journal of Molecular Structure, 1141, 268-275. doi: 10.1016/j.molstruc.2017.03.092

7 Lee, B., Shin, M., Seo, Y., Kim, M.H., Lee, H.R., Kim, J.S., \& Kim, Y.G. (2018). Synthesis of 2,4,6,8,9,11hexaaza[3.3.3]propellanes as a new molecular skeleton for explosives. Tetrahedron, 74(1), 130-134. doi: 10.1016/j.tet.2017.11.046

8 Qiu, H., Rong, J., Li, S., Tong, W., Zhang, T., \& Yang, L. (2014). Preparation, Crystal Structure, Thermal Decomposition, and DFT Calculation of a Novel 3D Infinite Structure Coordination Polymer $\left[\mathrm{Na}_{2}\left(\mathrm{H}_{2} \mathrm{O}\right)_{4}(\mathrm{ITDO})_{2}\right]_{\mathrm{n}}(\mathrm{ITDO}=2 \mathrm{H}$-imidazo-[4,5-e]-as1,2,4-triazine-2,7-dihydro-3,6-dione). Zeitschrift Für Anorganische Und Allgemeine Chemie, 641(2), 424-429. doi: 10.1002/zaac.201400413

9 Popović, T., Sokolić, L., Modrić, N., Palković, A., \& Poje, M. (1991). Synthesis and structure of dehydro-4-iminoallantoin and its covalent adducts. Tetrahedron, 47(2), 317-322. doi:10.1016/s0040-4020(01)80927-3

10 Kulasegaram, S., Shaheen, U., Turney, T.W., Gatesc, W.P., \& Patti, A.F. (2015). Zinc monoglycerolate as a catalyst for the conversion of 1,3- and higher diols to diurethanes. RAC Advances, 59, 47809-47812. doi: 10.1039/C5RA05032D

\section{Information about authors:}

Minakova Anastasia Aleksandrovna (corresponding author) — Junior Research Scientist at the Laboratory of High-Energy Compounds Synthesis, Institute for Problems of Chemical and Energetic Technologies, Siberian Branch of the Russian Academy of Sciences (IPCET SB RAS), Russia; e-mail: nastya.sinitsyna.1994@mail.ru. ORCID: https://orcid.org/0000-0003-3850-3132

Chikina Maya Victorovna - Candidate of chemical sciences, Research Scientist at the Laboratory of High-Energy Compounds Synthesis, Institute for Problems of Chemical and Energetic Technologies, Siberian Branch of the Russian Academy of Sciences (IPCET SB RAS), e-mail: chikina_maya@mail.ru. ORCID: https://orcid.org/0000-0002-1783-7718

Sergey Gavrilovich II'yasov - Doctor of Chemical Sciences, Deputy Director for Research, Head of Laboratory, Laboratory of High-Energy Compounds Synthesis, Institute for Problems of Chemical and Energetic Technologies, Siberian Branch of the Russian Academy of Sciences (IPCET SB RAS), Russia; e-mail: ilysow@ipcet.ru. ORCID: https://orcid.org/0000-0002-7853-6118 